\title{
市販フライ食品からの抽出油脂における家鬼赤血球の 溶血量と理化学的指標との相関
}

(昭和 58 年 12 月 26 日受理)

\author{
豊田正武* 伊藤誉志男* 原田 基夫*
}

\section{Relationship between Rabbit Erythrocyte Hemolysis and Chemical and Physical Indices of Oils Extracted from Commercial Fried Foods}

\author{
Masatake Toyoda, Yoshio Ito and Motoo Harada \\ (National Institute of Hygienic Sciences, Osaka Branch: 1-1-43, \\ Hoenzaka, Higashi-ku, Osaka, Japan)
}

\begin{abstract}
Key words: フライ食品 fried food; 溶血試験 hemolysis test; 酸価 acid value; カルボニル価 carbonyl value; 過酸化物価 peroxide value; 泡立ち foaming
\end{abstract}

著者らはさつま揚に使用後のフライ油について，家鬼 赤血球を用い $50 \%$ 溶血に必要なフライ油量 $\left(\mathrm{C}_{50}\right)$ を測 定したところ, フライ油の $\mathrm{C}_{50}$ が経時的に $4.35 \mathrm{mg}$ か ら $1.30 \mathrm{mg}$ 一低下することを報告し1), 本法がフライ 油の劣化の生物学的評価方法の 1 つとして使用できる可 能性を示した. そこで今回, 市販の各種フライ食品から 抽出した油脂について $\mathrm{C}_{50}$ を測定し, 同時に油脂劣化の 化学指標としての過酸化物価 (POV), 酸価 (AV), 総力 ルボニル価 $(\mathrm{COV})$ 及び物理指標としての泡立ち性との 比較を行ったので報告する.

\section{実験方法}

1. 試薬

エチルエーテル：過酸化物を除去したもの.

2. 試料

1）フライ食品：同一フライ食品はいずれも異なる店 舗より 1 検体ずつ購入した。すなわち，さつま揚はスー パー 1 店舗, マーケット 7 店舗, デパート 3 店舗, 小売 店 8 店舗より計 19 検体購入し, 油揚はマーケット 9 店 舗，小売店 6 店舗より計 15 検体購入し，いか天ぷらはス 一パー及びデパート各 1 店舗, マーケット 7 店舗, 小売 店 3 店舗より計 12 検体購入し, その他の生揚は小売店 3 店舗より 3 検体, ごぼう巻は小売店 2 店舗及びデパート

* 国立衛生試験所大阪支所：大阪市東区法円坂 1-143
1 店舗より 3 検体, 魚フライはマーケット, 小売店及び デパート各 1 店舗より 3 検体，がんもどきは小売店 1 店 舗より 1 検体，並びそコロッケは小売店 1 店舗より 1 検 体計 11 検体を購入した. 各検体は 1 晚冷蔵後抽出操作を 行った.

2) 新鮮油：大阪府内の小売店より調合油 3 検体（大 豆油と菜種油の混合油 2 検体, 菜種油之綿実油の混合油 1 検体）を購入した.

3） 使用済フライ油：大阪府内の家庭より 3 検体入手 した.

\section{3. 油脂の抽出方法}

さつま揚，がんもどきと油揚はそのまま，いか天ぷら と魚フライは中身を除去した衣，コロッケは内部のばれ いしょを除去した部分, 生揚は内部の豆腐を除去した部 分を，ごぼう巻はごぼうを除去した部分を，それぞれ約 $100 \mathrm{~g}$ 採り，エチルエーテル約 $200 \sim 300 \mathrm{ml}$ 及び無水硫 酸ナトリウム約 50〜100 gを加光，2 時間時々振とうし ながら浸漬抽出した．抽出液はろ過し，ろ液は窒素ガス 気流下で減圧乾固し, 残渣を抽出油脂として分析した.

\section{4. 抽出油脂の $\mathrm{C}_{50}$ の測定}

抽出油脂はアセトンに溶解した後，既報1) 飞従い家鬼 赤血球を用い $37^{\circ}$ で15分間反応し，遠沈上清の $540 \mathrm{~nm}$ そ执ける吸光度を測定し， $50 \%$ 溶血に必要な油脂量を 求めた. 


\section{5. 抽出油脂の化学的品質試験}

POV, AV, COV は基準油脂分析試験法 ${ }^{2}$ 飞従い行っ た.

\section{6. 抽出油脂の泡立ち性試験}

太田ら ${ }^{3)}$ の方法に準じ， $\phi 1.5 \times 16 \mathrm{~cm}$ のガラスフィ ルター (G-4) 付試験装置に約 $2 \sim 3 \mathrm{~g}$ の抽出油脂を入 れ, $180^{\circ}$ の油浴中に浸漬し, $7 \mathrm{ml} / \mathrm{min}$ の流速で窒素ガ スを通し，生成する泡の高さ $(\mathrm{mm})$ を測定した.

\section{結果及び考察}

\section{1. 新鮮油と使用済フライ油の $\mathrm{C}_{50}$ の比較}

新鮮油 3 検体の $\mathrm{C}_{50}$ は $5.00,5.10$ 及び $6.15 \mathrm{mg}$ (平 均 $5.4 \mathrm{mg}$ ) で, 家庭からの使用済フライ油 3 検体の $\mathrm{C}_{50}$ は $2.80,3.00$ 及び $3.30 \mathrm{mg}$ (平均 $3.0 \mathrm{mg}$ ) であった. 新鮮油の值は既報 ${ }^{1)}$ の新鮮菜種油の $\mathrm{C}_{50}(4.35 \mathrm{mg})$ より 若干高いが，これは本実験に用いたフライ油は購入直後 に測定したためと思われる。 また使用済フライ油の値は 既報1)のさつま揚を 3 日間自動フライした菜種油の $\mathrm{C}_{50}$ (2. $80 \mathrm{mg})$ 飞近い值である.

\section{2. フライ食品から抽出した油脂の $\mathrm{C}_{50}$ の食品群別比 較}

57 検体の食品試料から抽出した油脂について $\mathrm{C}_{50}$ を 測定し, さつま揚, 油揚, いか天ぷら，その他の食品の 4 群に分け, Table 1 に各測定值と, 各群毎の $\mathrm{C}_{50}$ の最 小值, 最大値, 平均值と標準偏差及び全群を合せた場合 の数值を示した. さつま揚から抽出した油脂の $\mathrm{C}_{50}$ の平 均値は, 既報のさつま揚を 9 日間自動フライした菜種油 の $\mathrm{C}_{50}(2.00 \mathrm{mg})$ 飞近く, 他のフライ食品から抽出した 油脂の $\mathrm{C}_{50}$ より低かった，すなわちさつま揚，いか天ぷ ら及び油揚について検体採取が十分ランダムに行われた と仮定した場合，さつま揚の $\mathrm{C}_{50}$ の平均值は他の 2 者の 平均值より有意 $(\mathrm{p}<0.01)$ 飞低かった。 しかし, 油揚 15 検体中 5 例，いかフライ 12 検体中 1 例，ごぼう巻 3 検体 中 1 例，魚フライ 3 検体中 1 例に新鮮油と同等あるいは より大きい $\mathrm{C}_{50}$ の值が見られた。このこともさつま揚の $\mathrm{C}_{50}$ と他の食品より抽出した油脂の $\mathrm{C}_{50}$ との差が大きい 理由の 1 つと思われる. な和 Table 2 に，抽出油脂の

Table 1. Determination of $50 \%$ Hemolysis $\left(\mathrm{C}_{50}\right)$ of Oils Extracted from Several Kinds of Fried Foods

\begin{tabular}{|c|c|c|c|c|c|c|c|c|}
\hline \multirow[t]{2}{*}{ Kinds of foods } & \multicolumn{5}{|c|}{$\mathrm{C}_{50}(\mathrm{mg})$} & \multirow{2}{*}{$\begin{array}{l}\text { Min. } \\
0.77\end{array}$} & \multirow{2}{*}{$\begin{array}{r}\text { Max. } \\
4.00\end{array}$} & \multirow{2}{*}{$\frac{\text { Mean } \pm \text { S. D. }}{2.24 \pm 0.86(n=19)}$} \\
\hline & 0.77 & 0.89 & 1.04 & 1.53 & 1.72 & & & \\
\hline "Satsuma-age" & 1.74 & 1.78 & 1.88 & 2. 10 & 2.26 & & & \\
\hline \multirow{2}{*}{ (Fried fish jelly product) } & 2. 40 & 2.55 & 2.65 & 2.78 & 2.92 & & & \\
\hline & 3. 02 & 3.25 & 3.27 & 4.00 & & & & \\
\hline \multirow{3}{*}{$\begin{array}{l}\text { "Abura-age" } \\
\text { (Fried soy-bean curd) }\end{array}$} & 0.96 & 1. 36 & 1. 61 & 2.19 & 2.26 & 0.96 & 7. 45 & $3.89 \pm 2.12(\mathrm{n}=15)$ \\
\hline & 2.85 & 3.15 & 3.55 & 3.62 & 4.44 & & & \\
\hline & 5.74 & 6.25 & 6.45 & 6.48 & 7. 45 & & & \\
\hline \multirow{3}{*}{ Fried squid } & 0.88 & 1.59 & 3.51 & 3.65 & 3.69 & 0.88 & 5.70 & $3.62 \pm 1.26(\mathrm{n}=12)$ \\
\hline & 3.82 & 3.90 & 4.04 & 4. 11 & 4.24 & & & \\
\hline & 4.31 & 5.70 & & & & & & \\
\hline \multicolumn{9}{|l|}{ Other fried foods } \\
\hline “Nama-age" & 1.98 & 2.78 & 4.12 & & & 1.98 & 7.43 & $3.86 \pm 1.50(n=15)$ \\
\hline "Gobō-maki" & 3.02 & 3.33 & 7.43 & & & & & \\
\hline Fried fish & 3.95 & 4.40 & 5.45 & & & & & \\
\hline "Ganmodoki" & 2.90 & & & & & & & \\
\hline \multirow[t]{2}{*}{ Croquettes } & 3.15 & & & & & & & \\
\hline & & & & & & 0.77 & 7.45 & $3.28 \pm 1.62(\mathrm{n}=57)$ \\
\hline
\end{tabular}

Table 2. Frequency Distribution of $\mathrm{C}_{50}$ of Oils Extracted from Several Kinds of Fried Foods

\begin{tabular}{|c|c|c|c|c|c|c|c|c|c|}
\hline \multirow[b]{2}{*}{ Kinds of foods } & \multirow{2}{*}{$\begin{array}{l}\text { Number } \\
\text { of } \\
\text { samples }\end{array}$} & \multicolumn{8}{|c|}{ Range of $\mathrm{C}_{50}(\mathrm{X}: \mathrm{mg})$} \\
\hline & & $\mathrm{X} \leqq 1.0$ & $\begin{array}{r}1.0<\mathrm{X} \\
\leqq 2.0\end{array}$ & $\begin{array}{r}2.0<\mathrm{X} \\
\leqq 3.0\end{array}$ & $\begin{array}{r}3.0<\mathrm{X} \\
\leqq 4.0\end{array}$ & $\begin{array}{r}4.0<\mathrm{X} \\
\leqq 5.0\end{array}$ & $\begin{array}{r}5.0<\mathrm{X} \\
\leqq 6.0\end{array}$ & $\begin{array}{r}6.0<\mathrm{X} \\
\leqq 7.0\end{array}$ & $\begin{array}{r}7.0<\mathrm{X} \\
\leqq 8.0\end{array}$ \\
\hline "Satsuma-age" & 19 & 2 & 6 & 7 & 4 & 0 & 0 & 0 & 0 \\
\hline "Abura-age" & 15 & 1 & 2 & 3 & 3 & 1 & 1 & 3 & 1 \\
\hline Fried squid & 12 & 1 & 1 & 0 & 5 & 4 & 1 & 0 & 0 \\
\hline Other fried foods & 11 & 0 & 1 & 2 & 4 & 2 & 1 & 0 & 1 \\
\hline Total number & 57 & 4 & 10 & 12 & 16 & 7 & 3 & 3 & 2 \\
\hline
\end{tabular}




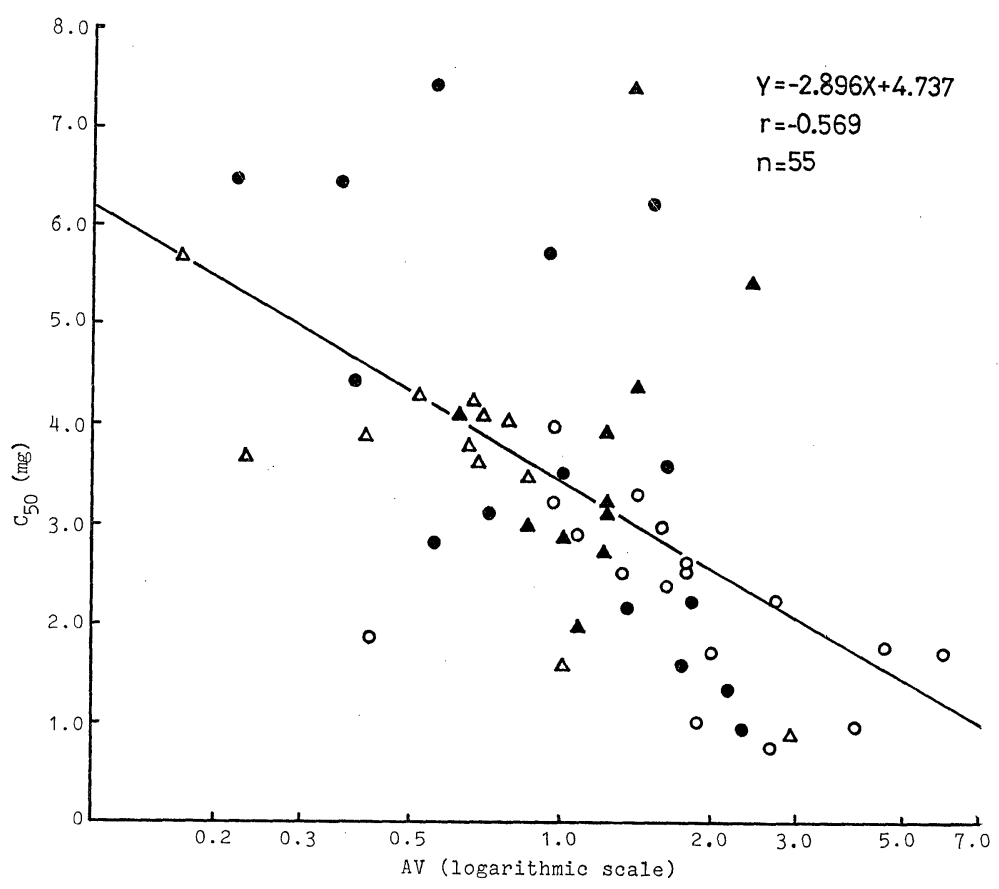

Fig. 1. Correlation between $\mathrm{C}_{50}$ and acid value of oils extracted from fried foods o, "Satsuma-age"

-, "abura-age" $\Delta$, fried squid $\Delta$, other fried foods

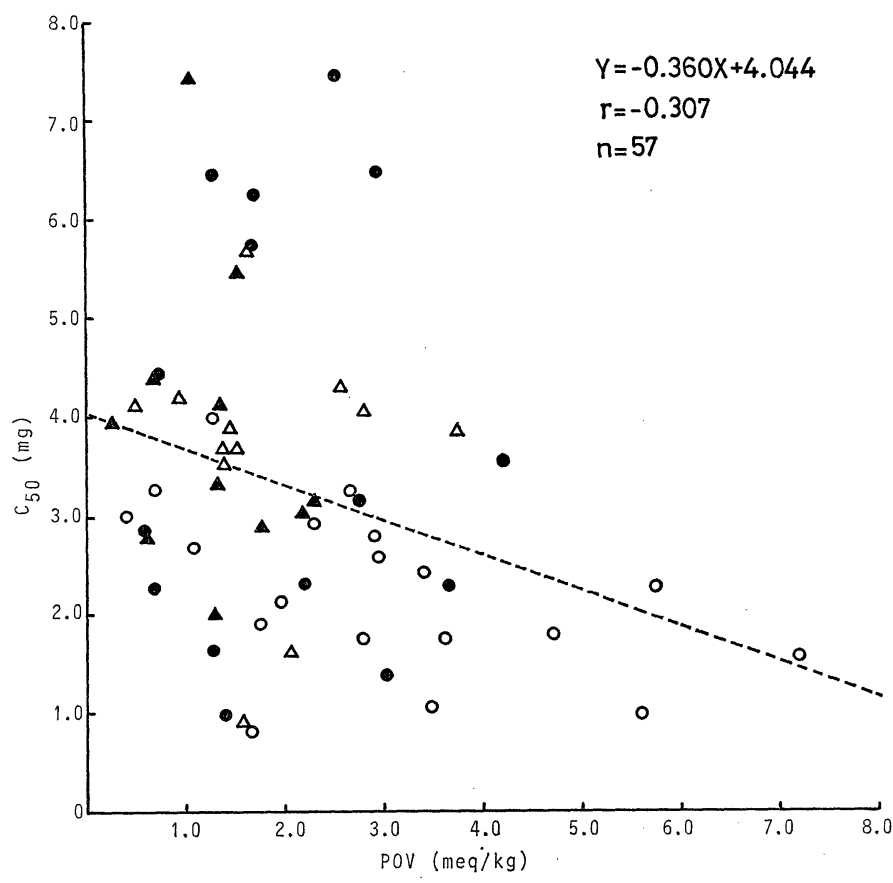

Fig. 2. Correlation between $\mathrm{C}_{50}$ and peroxide value of oils extracted from fried foods ○, "Satsuma-age" $\bullet$, "abura-age" $\Delta$, fried squid $\Delta$, other fried foods 


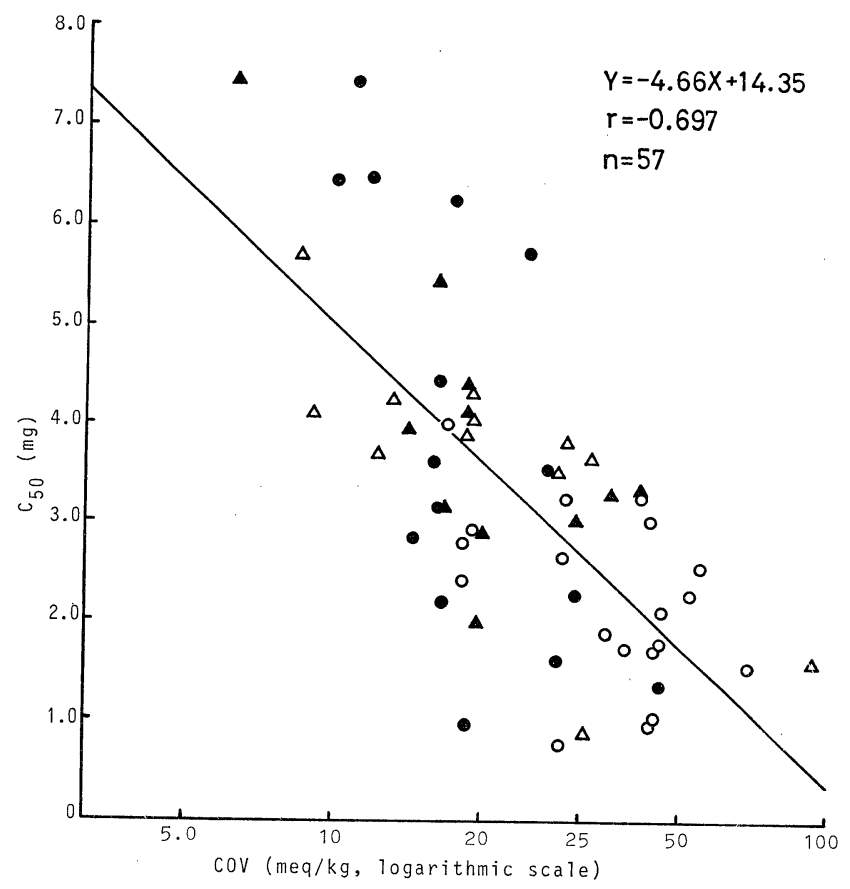

Fig. 3. Correlation between $\mathrm{C}_{50}$ and carbonyl value of oils extracted from fried foods o, "Satsuma-age"

-, "abura-age" $\triangle$, fried squid $\Delta$, other fried foods

$\mathrm{C}_{50}$ について, $0 \sim 8 \mathrm{mg}$ まで $1 \mathrm{mg}$ ごとに分類した場合 の頻度分布を 4 食品群別に示した.

3. フライ食品から抽出した油脂の $\mathrm{C}_{50}$ と AV, POV, $\mathrm{COV}$, 泡立ち性との相関性の比較

フライ食品から抽出した油脂について, AV, POV 及 び COV を測定し， $\mathrm{C}_{50}$ との相関を調べた. Fig. 1 に 示す通り, $\mathrm{C}_{50}$ と $\mathrm{AV}$ の対数值との間には相関 $(\mathrm{r}=$ -0.569) が認められ, AV の増加と共に $\mathrm{C}_{50}$ は低下し た. 揚げ菓子の指導要領で規制している $\mathrm{AV} 3^{4}$ ) 以上の 油脂が 3 検体見られた. なお $\mathrm{AV}$ が 3 に相当する $\mathrm{C}_{50}$ の值は約 2.0 である. $\mathrm{C}_{50}$ と $\mathrm{POV}$ との相関は Fig. 2 に示す通り低く $(r=-0.307)$, 食品別ではさつま揚か ら抽出した油脂のみ相関 $(\mathrm{r}=-0.505)$ が見られたが, この原因は明らかでない.また Fig. 3 に示す通り， $\mathrm{C}_{50}$ と COV の対数值との相関は最も高く $(\mathrm{r}=-0.697)$, $\mathrm{COV}$ の上昇と共に $\mathrm{C}_{50}$ は低下した. なお, そうざいの 衛生規範 ${ }^{5)}$ ではフライに使用する油脂のカルボニル価を 50 以下と規制しているが，本報告の抽出油脂57検体中 4 検体がこの数值を超えていた. また COV の 50 に相当 する $\mathrm{C}_{50}$ の值は概略 2.0 で, これは前記の $\mathrm{AV}$ の 3 に 対応する $\mathrm{C}_{50}$ の值と一致した. $\mathrm{AV}$ 又は $\mathrm{COV}$ の規制值 を超える劣化した油脂が, 同一水準の 2.0 以下の $\mathrm{C}_{50}$ 值を示すことは, $\mathrm{C}_{50}$ 值による劣化油脂の評価の参考に なるものと思われる。
一般に長時間使用した油で揚物をすると, 細かく消え にくい泡が立つことが知られている. 従って，そのよう な場合には揚物に移行した油も同様な性質を示すものと 思われ，揚物から抽出した油脂の泡立ち性を比較するこ とによりフライに用いた油の品質を推察でさるのではな いかと考えられた. そこで, 抽出油脂の泡立ち性を泡の 高さで測定したところ, 油揚から抽出した油脂は揚種の 大豆由来の成分の混入によると考えられる測定不可能な 泡が多量生成した. 従って, 油揚から抽出した油脂を除 いた36検体の抽出油脂について， $\mathrm{C}_{50}$ と泡の高さとの相 関を比較した. Fig. 4 に示す通り, 0〜50 mm の泡の高 さを示す油脂では， $\mathrm{C}_{50}$ の低下と共に泡立ち性も上昇し た（r=-0.615）が, 前述のように例外も多く, 抽出油 を用いた場合には揚種の種類により泡立ら性が異なるこ とに注意すべきである.な敃図中泡の高さが $3 \sim 5 \mathrm{~mm}$ の場合は大きな泡で，10～ $20 \mathrm{~mm}$ 以上の場合は小さな 泡が生成した.

\section{4 フライ食品群別の抽出油脂の $\mathrm{C}_{50}, \mathrm{AV}, \mathrm{POV}$, COV 及び泡立ち性の比較}

Table 3 に 4 食品群別の抽出油脂の $\mathrm{C}_{50}$ の平均值を, 劣化の化学指標である $\mathrm{AV}, \mathrm{POV}, \mathrm{COV}$ 及び物理指標 である泡の高さの各平均值と比較した結果を示した.さ つま揚から抽出した油脂では, AV, POV, COV 及び泡 の高さの平均值はいずれも総平均值より高く, 一方他の 


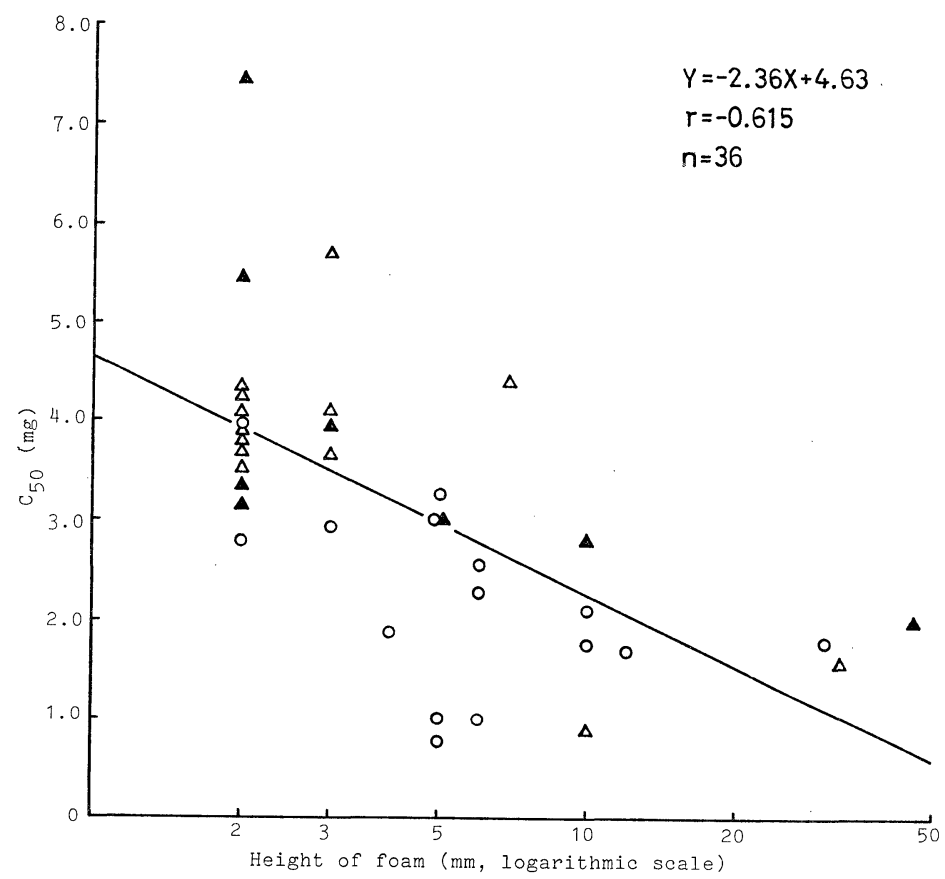

Fig. 4. Correlation between $\mathrm{C}_{50}$ and foaming quantities of oils extracted from fried foods

O, "Satsuma-age" $\Delta$, fried squid $\Delta$, other fried foods

Table 3. Comparison of Average $\mathrm{C}_{50}$, Acid Value, Peroxide Value and Height of Foam among Oils Extracted from Various Fried Foods

\begin{tabular}{|c|c|c|c|c|c|}
\hline Kind of foods & $\begin{array}{l}\mathrm{C}_{50} \\
(\mathrm{mg})\end{array}$ & $\mathrm{AV}$ & $\begin{array}{c}\text { POV } \\
(\mathrm{meq} / \mathrm{kg})\end{array}$ & $\underset{(\mathrm{meq} / \mathrm{kg})}{\mathrm{COV}}$ & $\begin{array}{l}\text { Height of foam } \\
(\mathrm{mm})\end{array}$ \\
\hline "Satsuma-age" & $\begin{array}{c}24 \pm 0.86 \\
(n=19)\end{array}$ & $\begin{array}{c}2.12 \pm 1.40 \\
(n=17)\end{array}$ & $\begin{array}{c}2.94 \pm 1.81 \\
(n=19)\end{array}$ & $\begin{array}{c}37.9 \pm 14.1 \\
(n=19)\end{array}$ & $\begin{array}{c}7.4 \pm 6.9 \\
(\mathrm{n}=15)\end{array}$ \\
\hline "Abura-age" & $\begin{array}{c}3.89 \pm 2.12 \\
(n=15)\end{array}$ & $\begin{array}{c}1.13 \pm 0.68 \\
(n=15)\end{array}$ & $\begin{array}{c}1.95 \pm 1.02 \\
(n=15)\end{array}$ & $\begin{array}{c}20.1 \pm 9.9 \\
(n=15)\end{array}$ & - \\
\hline Fried squid & $\begin{array}{c}3.62 \pm 1.26 \\
(n=12)\end{array}$ & $\begin{array}{c}0.78 \pm 0.69 \\
(n=12)\end{array}$ & $\begin{array}{c}1.81 \pm 0.88 \\
(n=12)\end{array}$ & $\begin{array}{c}26.4 \pm 23.0 \\
(n=12)\end{array}$ & $\begin{array}{r}5.4 \pm 8.7 \\
(n=12)\end{array}$ \\
\hline Other fried foods & $\begin{array}{c}3.84 \pm 1.50 \\
(n=11)\end{array}$ & $\begin{array}{c}1.23 \pm 0.44 \\
(n=11)\end{array}$ & $\begin{array}{c}1.30 \pm 0.63 \\
(n=11)\end{array}$ & $\begin{array}{c}22.0 \pm 9.7 \\
(n=11)\end{array}$ & $\begin{array}{c}8.8 \pm 14.2 \\
(\mathrm{n}=9)\end{array}$ \\
\hline Mean \pm S. D. & $\begin{array}{c}3.28 \pm 1.62 \\
(n=57)\end{array}$ & $\begin{array}{c}1.38 \pm 1.05 \\
(n=55)\end{array}$ & $\begin{array}{c}2.12 \pm 1.38 \\
\quad(n=57)\end{array}$ & $\begin{array}{c}27.7 \pm 16.3 \\
(n=57)\end{array}$ & $\begin{array}{c}7.1 \pm 9.5 \\
(n=36)\end{array}$ \\
\hline
\end{tabular}

3 食品群から抽出した油脂の AV, POV, COV の各平均 值はいずれも総平均值より低い值を示した.これはさつ ま揚のような動物性の材料を直接フライすると, フライ 油の劣化が著しい事実 ${ }^{6)}$ と良く対応している， $C_{50}$ の食 品群別平均值を比較した場合も同様の傾向が見られ, さ つま揚から抽出した油脂の $\mathrm{C}_{50}$ は総平均值より低い值を 示した。

以上の調査結果より，フライ食品から抽出した油脂の $\mathrm{C}_{50}$ 及び物理・化学的な油脂の劣化指標值が食品（揚種）
により影響を受けることが推察された。 しかし $\mathrm{C}_{50}$ 值と $\mathrm{AV}$ 及び COV とが一定の関係をもって変動することも 認められたので, 前報 ${ }^{1)}$ で考察した $\mathrm{C}_{50}$ がフライ食品の 油脂劣化の生物学的指標となり得ることが確認された. しかし油揚より抽出した油脂を中心に新鮮油より高い $\mathrm{C}_{50}$ を示す例の見られることは，抽出油脂中に溶血を抑 制する成分の存在を暗示しているようであり，今後解明 する必要がある. 


\section{要 約}

1) 市販フライ食品 57 検体から抽出した油脂につい て, 家鬼赤血球を用い $50 \%$ 溶血に必要な油脂量 $\left(\mathrm{C}_{50}\right.$ : $\mathrm{mg})$ と AV, POV, $\mathrm{COV}$ 及び泡立ち性との関係を調べ た.

2) 新鮮天ぷら油で $\mathrm{C}_{50}$ は $5.00 \sim 6.15 \mathrm{mg}$ (平均 5.4 $\mathrm{mg}$ ), 家庭での使用済フライ油で $2.80 \sim 3.30 \mathrm{mg}$ (平均 $3.0 \mathrm{mg}$ ) であった.

3）フライ食品から抽出した油脂の $\mathrm{C}_{50}$ は，さつま揚 で $0.77 \sim 4.00 \mathrm{mg}$ (平均 $2.24 \mathrm{mg}$ ), 油揚で $0.96 \sim 7.45$ $\mathrm{mg}$ (平均 $3.89 \mathrm{mg}$ ), いか天ぷらで 0.88〜 $5.70 \mathrm{mg}$ (平 均 $3.62 \mathrm{mg}$ ), ごぼう巻, 魚フライ, 生揚などのその他 のフライ食品で $1.98 \sim 7.43 \mathrm{mg}$ (平均 $3.86 \mathrm{mg}$ ) で，さ つま揚の $\mathrm{C}_{50}$ 值は低かった。

4) 抽出油脂の $\mathrm{C}_{50}$ は, $\mathrm{AV}, \mathrm{COV}$ 及び泡の高さ(油 揚を除く）と相関し，POV との相関は低かった。

謝辞

本研究に当り, 家鬼新鮮血を実験ごとに御供与下さい
ました当所薬理微生物部川崎浩之進室長に深謝いたしま す.

なお本研究は日本食品衛生学会第46回学術講演会（19 83 年10月, 山形) において発表した.

文献

1）豊田正武，井崎や总子，原田基夫：食衛誌。24, 545 549 (1983).

2）日本油化学協会編：基準油脂分析試験法，2.4. 12-71, 2. 4. 1-71, 24. 22-73 (1980).

3) 太田静行, 岩田直樹, 森田昌治: 油化学, 13,210 $\sim 217$ (1964).

4）東島弘明：食品衛生研究，28，90１06 (1978).

5）厚生省食品衛生監視研究会監修, 藤原喜久夫編： “弁当，そうざいの衛生” p. 62 (1980) 中央法規 出版.

6)薄木理一郎，鷹左右紀子，金田尚志：食品工誌。 27, 332 336 (1980). 